\title{
Antibody Response and Haematological Changes of Nigerian Locally Adapted Turkeys to Sheep Red Blood Cells (SRBC)
}

\author{
Ayodele Emmanuel OGUNDER0 ${ }^{1 *}$, Mofoyeke Oluwayemisi SANDA ${ }^{1}$, \\ Adeyemi Sunday ADENAIKE ${ }^{1}$, Michael Irewole TAKEET ${ }^{2}$, Christian Obiora Ndubuisi IKEOBI ${ }^{1}$ \\ ${ }^{1}$ Department of Animal Breeding and Genetics, Federal University of Agriculture, Abeokuta, Ogun State, \\ Nigeria. \\ ${ }^{2}$ Department of Veterinary Microbiology and Parasitology, Federal University of Agriculture, Abeokuta, \\ Ogun State, Nigeria. \\ *corresponding author: ogunderoayo@gmail.com
}

Bulletin UASVM Animal Science and Biotechnologies 77(2)/2020

ISSN-L 1843-5262; Print ISSN 1843-5262; Electronic ISSN 1843-536X

DOI:10.15835/buasvmcn-asb: 2020.0005

\begin{abstract}
Haemagglutination assay and haematological analysis of 143 poults generated as $\mathrm{F}_{1}$ individuals by artificial insemination from randomly selected turkeys of White, Black and Lavender genotypes which are classified by antibody titre was carried out so as to confirm their antibody titre levels in response to sheep red blood cells (SRBC). Results showed that mean values obtained for high and low antibody titres were 7.31 and 2.67 respectively, resulting in the classification of the turkeys into Black high and low, Lavender high and black, and White high and low antibody titres. The genotype's titre had significant $(\mathrm{P}<0.05)$ effect on the packed cell volume (PCV), haemoglobin (Hb), red blood cells (RBC), white blood cells (WBC) and basophil (BAS) of the basal haematological parameters. Genotype's titre had no significant $(\mathrm{P}>0.05)$ effect on the primary response haematological parameters. Meanwhile, the primary response haematological parameters to SRBC antigen varied along the genotypes with the WBC increasing drastically in all the genotypes, signifying the presence of an antigen. The study concluded that the $\mathrm{F}_{1}$ turkey poult population studied diverged along the high and low antibody titre in response to SRBC. Thus, the $\mathrm{F}_{1}$ generation of the high antibody titre genotypes (Black high, White high and Lavender high) can be used as foundation stock for selection of local turkeys for high antibody titre.
\end{abstract}

Keywords: antibody titre, haematology, SRBC.

\section{Introduction}

An economically important trait in animals and poultry, including turkeys (Meleagris gallopavo), for which gene identification remains a challenge, is immune response, which can be either cellular or humoral (Tuoyu et al., 2015). Because antibodymediated immune response or antibody response may neutralize, destroy and remove invading pathogens from the animal body, an analysis of the molecular basis of antibody response may provide a basis for improving the natural resistance of animals to disease. The level of antibody production or antibody titre is a feature of antibody response. Consequently, antibody response selection may increase immunity to vertebrate disease (Gross et al., 1980; Tuoyu et al., 2015). Haematological parameters are being used in avian medicine as physiological indicators and disease diagnostic tools (Quintavalla et al., 2001). According to Adeyemo et al. (2018), the information gained from investigation of haematological values, disease diagnosis and managerial factors are 
the main tools for developing new genotypes of birds which are genetically able to resist different diseases.

Divergent selection for a single trait (antibody response) using a multi-determinant and nonpathogenic antigen such as sheep red blood cells (SRBC) is a direct and efficient way to create divergent populations (Lamont et al., 2003). Compared to a specific antigen, SRBC, a T-cell dependent, non-specific antigen, is preferentially used in studies to dissect molecular basis of antibody response.

According to Ogah (2011), turkeys are seldom raised by poultry farmers in Nigeria compared to chickens, however, several farms are beginning to breed the bird at commercial level owing to increasing interest as a provider of meat, complementing the chicken. Even though natural selection has led to the selection of some locally adapted breeds of turkeys which have come to adapt to the environment, the issue of disease outbreak is still of major concern to the farmers who are developing interest in turkey production because of the huge losses incurred when such a catastrophic disaster occurs (Okaroafor, 2014).

As consumers continue to voice concerns about the health and safety of foods derived from animals, it is important to find effective methods for reducing chronic antibiotic use and enhancing the effectiveness of vaccine protection by improving birds ' innate ability to respond to antigenic challenges through genetic selection (Lamont et al., 2003). Therefore, this research aimed at describing the resources that could identify foundation for improving the natural immune capacity of Nigerian locally adapted turkeys by identifying genotypes that have high immune response (i.e. high antibody titre value) to SRBC.

\section{Materials and Methods Experimental site}

The experiment was conducted at the poultry unit, Directorate of University Farms (DUFARMS) Federal University of Agriculture (FUNAAB) Abeokuta, Ogun State. The laboratory analysis was carried out at the Department of Animal Breeding and Genetics biotechnology laboratory, FUNAAB.

Experimental animals and management

A total of 143 poults used for this research were selected at random from the $\mathrm{F}_{1}$ generation of three genotypes of Nigerian locally adapted turkeys (Black, White and Lavender) that had shown divergent response (high or low antibody titre) to sheep red blood cells (SRBC) antigen. Antibiotic-free starter's mash (Energy: 3010Kcal/ Kg; Crude Protein: $23.00 \%$ ) and water was made available ad libitum.

\section{Sheep red blood cells (SRBC) preparation and inoculation of poults}

Approximately $5 \mathrm{ml}$ blood was withdrawn under aseptic condition from a healthy male sheep into an EDTA tube. The sheep blood was centrifuged at $3500 \mathrm{rpm}$ for 5 minutes and the supernatant was discarded. The sediment erythrocytes were given three washings with Phosphate buffered solution (PBS) at 3500rpm for 5 minutes. The packed erythrocytes were reconstituted in PBS to make $1 \%$ suspension of SRBC. The poults were immunised with $1 \mathrm{ml}$ of the $1 \%$ suspension of SRBC at $6^{\text {th }}$ week through the brachial vein.

\section{Blood and sera collection}

Approximately $1 \mathrm{ml}$ of blood samples were collected through the brachial vein at the $5^{\text {th }}$ week for basal haematology evaluation before injection of SRBC. At ${ }^{\text {th }}$ week blood samples was also collected 5 days after SRBC injection for the post-primary (PPI) haematological examination and haemagglutination assay. Sera were harvested and stored at $-4^{\circ} \mathrm{C}$ until all samples were analysed simultaneously for total antibodies to determine the antibody titres for the primary response and to evaluate the antibody titre levels among the $\mathrm{F}_{1}$ progeny from their parent's titre level.

\section{Haemagglutination assay}

Sera harvested from each poult were used to determinethe antibody titres by haemagglutination assay as described by Wegmann and Smithies (1966). The anti-serum underwent 2-fold dilution multiple times in a V-bottomed 96-well plate containing $1 \%$ suspension of SRBC, and then this mixture was incubated at $37^{\circ} \mathrm{C}$ for 45 minutes for antibody titre reading. Titres were expressed as $\log _{2}$ of the reciprocal of the highest dilution in which there was complete haemagglutination. Titres with complete haemagglutination $<4$ were classified as low titres, while $\geq 5$ were classified as high titre.

\section{Haematology evaluation}

Blood collected before the injection and fivedays post-injection of SRBC at $6^{\text {th }}$ week from the poults was be taken to the Haematology Labora- 
tory, College of Veterinary Medicine, FUNAAB to evaluate the following parameters: packed cell volume (PCV), haemoglobin (Hb), red blood cells (RBC), white blood cells (WBC), heterophil (HET), lymphocytes (LYM), eosinophil (EOS), basophil (BAS), mean corpuscular volume (MCV), mean concentration haemoglobin $(\mathrm{MCH})$ and mean corpuscular haemoglobin concentration (MCHC) for the basal and primary responses to SRBC using standard procedures.

\section{Statistical analysis}

The differences between the observed and expected numbers of antibody titre levels was compared using a goodness-of-fit Chi-Square $\left(\mathrm{X}^{2}\right)$ test.

$$
X^{2}=\sum \frac{(o b s-e x p)^{\llcorner}}{\exp }
$$

Homogeneity test of haematological parameters was carried out while the antibody titre values of the $\mathrm{F}_{1}$ progeny were transformed to reciprocal $\log _{2}$ units of greatest dilution showing $100 \%$ agglutination prior to analysis. Analysis of variance of both untransformed and transformed data was performed using the General Linear Models (GLM) procedure of the SAS ${ }^{\circledR}$ University Edition (Copyright (C) 2018, SAS Institute Inc.) to evaluate genotype differences in anti-SRBC titres within and among the Lavender High (LH), Lavender Low (LL), Black High (BH), Black Low (BL), White High (WH) and White Low (WL) genotypes. The basal values of the haematological parameters were used as covariate in the analysis.

$$
Y_{i j}=\mu+X \beta+G_{i}+e_{i j}
$$

where:

Table 1. Overall means \pm standard error of antibody titre of Nigerian locally adapted $F_{1}$ turkey poults primary response to SRBC

\begin{tabular}{ccccc}
\hline Antibody titre & N & Means \pm S.E. & Min & Max \\
\hline High & 54 & $7.31 \pm 0.27$ & 5 & 11 \\
\hline Low & 89 & $2.67 \pm 0.12$ & 1 & 4 \\
\hline
\end{tabular}

$\mathrm{N}=$ Number of Samples; Min = minimum; Max = maximum

$\mathrm{Y}_{\mathrm{ij}}$ - Observed performance of the $\mathrm{j}^{\text {th }}$ individual of the $\mathrm{i}^{\text {th }}$ genotype by titre level

$\mu$ - Overall mean for the parameters of interest

$\mathrm{X} \beta$ - Basal values of haematological parameters used as covariate

$\mathrm{G}_{\mathrm{i}}$ - Fixed effect of the $\mathrm{i}^{\text {th }}$ genotype $\left(\mathrm{i}^{\text {th }}=\mathrm{LH}, \mathrm{LL}, \mathrm{BH}\right.$, $\mathrm{BL}, \mathrm{WH}$ and $\mathrm{WL}$ )

$\mathrm{e}_{\mathrm{ijk}}$ - Residual error

Means were separated using the TukeyKramer Honest Significant Difference.

\section{Results}

Antibody response of Nigerian locally adapted $\mathrm{F}_{1}$ turkey poults to sheep blood cells (SRBC)

The mean values obtained for high and low antibody titres were 7.31 and 2.67 respectively (Table 1: Anti-log transformed). A significant difference $(\mathrm{P}<0.05)$ was observed among the genotypes, with the high antibody titre genotypes ( $\mathrm{LH}, \mathrm{WH}$ and $\mathrm{BH}$ ) having higher titre values than their low antibody titre (LL, BL and WL) counterparts (Table 2). Table 3 shows the Chisquare analysis of the $1^{\text {st }}$ filial generation of Nigerian locally adapted turkey primary response to SRBC. From a total population of 143, the observed high antibody titre population (54) is greater than the expected (43) while the observed low antibody titre population (89) is less than the expected (100). Thus, the chi-square statistic was significant $(\mathrm{P}<0.05)$ at with $\mathrm{P}$-value of 0.0449 .

Changes in haematological parameters of

Nigerian locally adapted $F_{1}$ turkey poults in response to sheep blood cells (SRBC)

The mean values of the following haematological parameters: packed cell volume (PCV), haemoglobin ( $\mathrm{Hb})$, red blood cells (RBC), white blood cells (WBC), heterophil (HET), lymphocytes (LYM), eosinophil (EOS), basophil (BAS), mean corpuscular volume (MCV), mean concentration haemoglobin $(\mathrm{MCH})$ and mean corpuscular 
Table 2. Means \pm standard error of antibody titre of Nigerian locally adapted $F_{1}$ turkey poults primary response to SRBC

\begin{tabular}{ccc}
\hline Genotypes & Sample No. & Means \pm S.E. \\
\hline Black High & 16 & $7.12 \pm 0.48^{\mathrm{a}}$ \\
\hline Black Low & 26 & $2.61 \pm 0.21^{\mathrm{b}}$ \\
\hline Lavender High & 22 & $7.50 \pm 0.41^{\mathrm{a}}$ \\
\hline Lavender Low & 23 & $2.91 \pm 0.19^{\mathrm{b}}$ \\
\hline White High & 16 & $7.25 \pm 0.52^{\mathrm{a}}$ \\
\hline White Low & 40 & $2.57 \pm 0.18^{\mathrm{b}}$ \\
\hline
\end{tabular}

${ }^{\mathrm{a}, \mathrm{b}}$ Means within the same column with different superscripts differ significantly $(\mathrm{P}<0.05)$

Table 3. Chi-Square $\left(\chi^{2}\right)$ for antibody primary response of Nigerian locally adapted $\mathrm{F}_{1}$ turkey poults to SRBC

\begin{tabular}{ccccc}
\hline Antibody titre & Observed & Expected & P-value & $\chi^{2}$ \\
\hline High & 54 & 43 & 0.0449 & $4.0239^{*}$ \\
\hline Low & 89 & 100 & & \\
\hline Total & 143 & & & \\
\hline
\end{tabular}

$* \mathrm{P}<0.05$

haemoglobin concentration (MCHC) for Nigerian locally adapted $F_{1}$ turkey poult genotypes are presented in Tables 4 and 5 . Table 4 shows the basal haematological parameters of Nigerian locally adapted $\mathrm{F}_{1}$ turkey poults before inoculation with sheep red blood cells (SRBC). Significant differences $(\mathrm{P}<0.05)$ were observed only in the PCV, $\mathrm{Hb}, \mathrm{RBC}, \mathrm{WBC}$ and BAS. For the primary response haematological parameters after inoculation of SRBC, no significant differences $(P>0.05)$ was observed among the turkey genotypes (Table 5). Only the WBC haematological parameter for the primary response was greater than the basal WBC for all genotypes, while the basal parameters either increase or decrease relative to the primary response for other parameters.

\section{Discussion}

There are very practical (i.e. raising animals with natural resistance to infections) and economic (i.e. reduction in cost of production) reasons for pursuing enhancement of immunity via direct selection for immune response. A significant statistic obtained from the chi-square analysis in this study, testify to the fact from literatures (Siegel
\& Gross, 1980; van Der Zijpp \& Leenstra, 1980; Martin et al.,1990; Pinard et al.,1992; Kuehn et al., 2006) that the pattern of inheritance of antibody response of avian to inoculation of SRBC responds to divergent selection i.e. the genes responsible for antibody response undergoes segregation which is expected because the populations from this study are the first generation of turkeys to be selected for high and low antibody response to SRBC. The significant differences observed between the high and low genotypes in this study is consistent with the findings of Pinard et al. (1992) who reported that after three generations, there were significant differences in antibody response between genotypes of ISA Warren chickens selected for high and low antibody titre at 5 days after immunization at 35 days of age with SRBC.

Packed Cell Volume (PCV) or haematocrit is the proportion of blood volume that is occupied by erythrocytes i.e. the ratio of red blood cells to the whole blood volume. The PCV values of the basal and primary responses across all the genotypes of turkeys observed in this study were within the normal range of $35.90-41.00 \%$ for avian stated by Mitruka and Rawnsley (1997), which means 


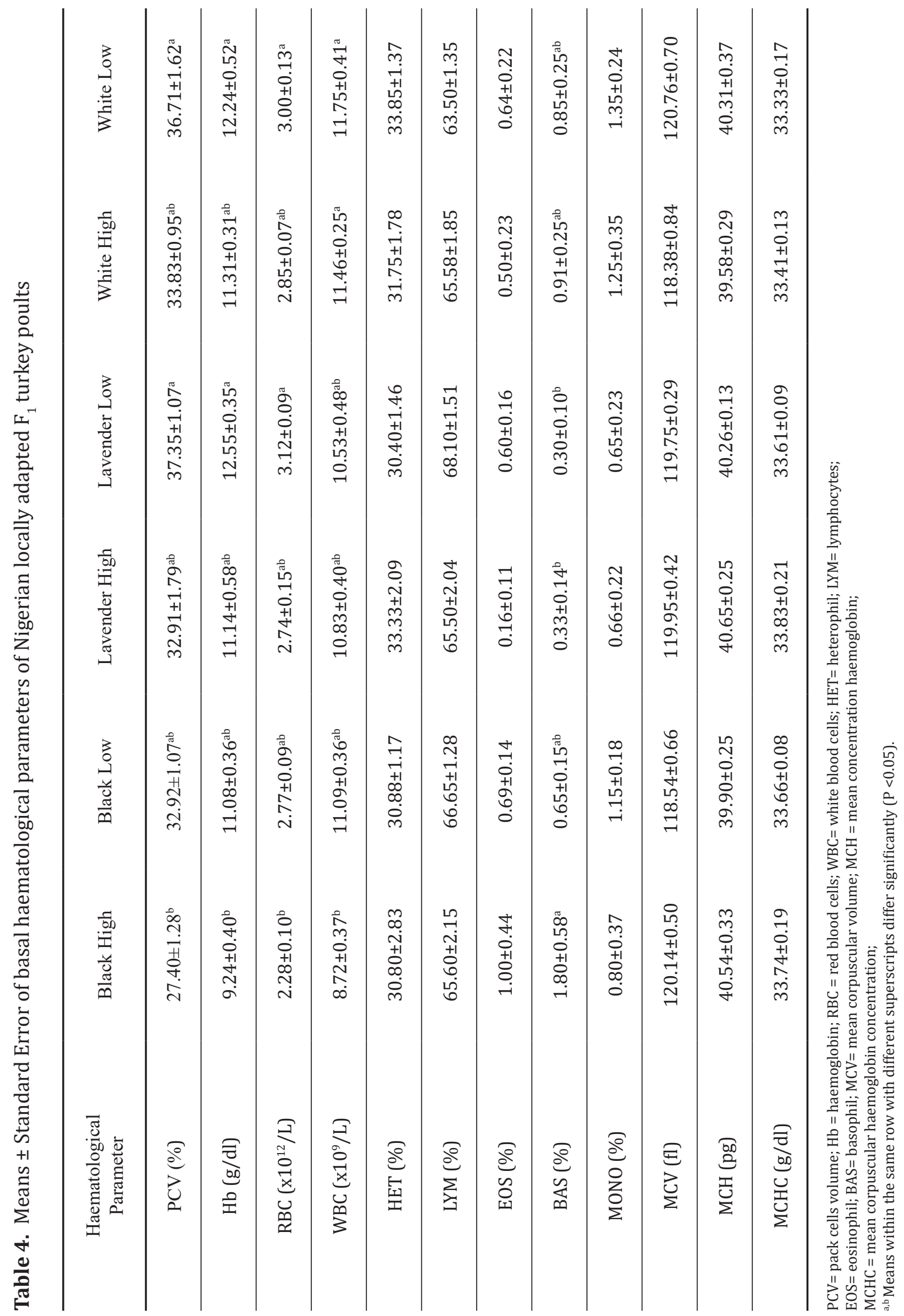




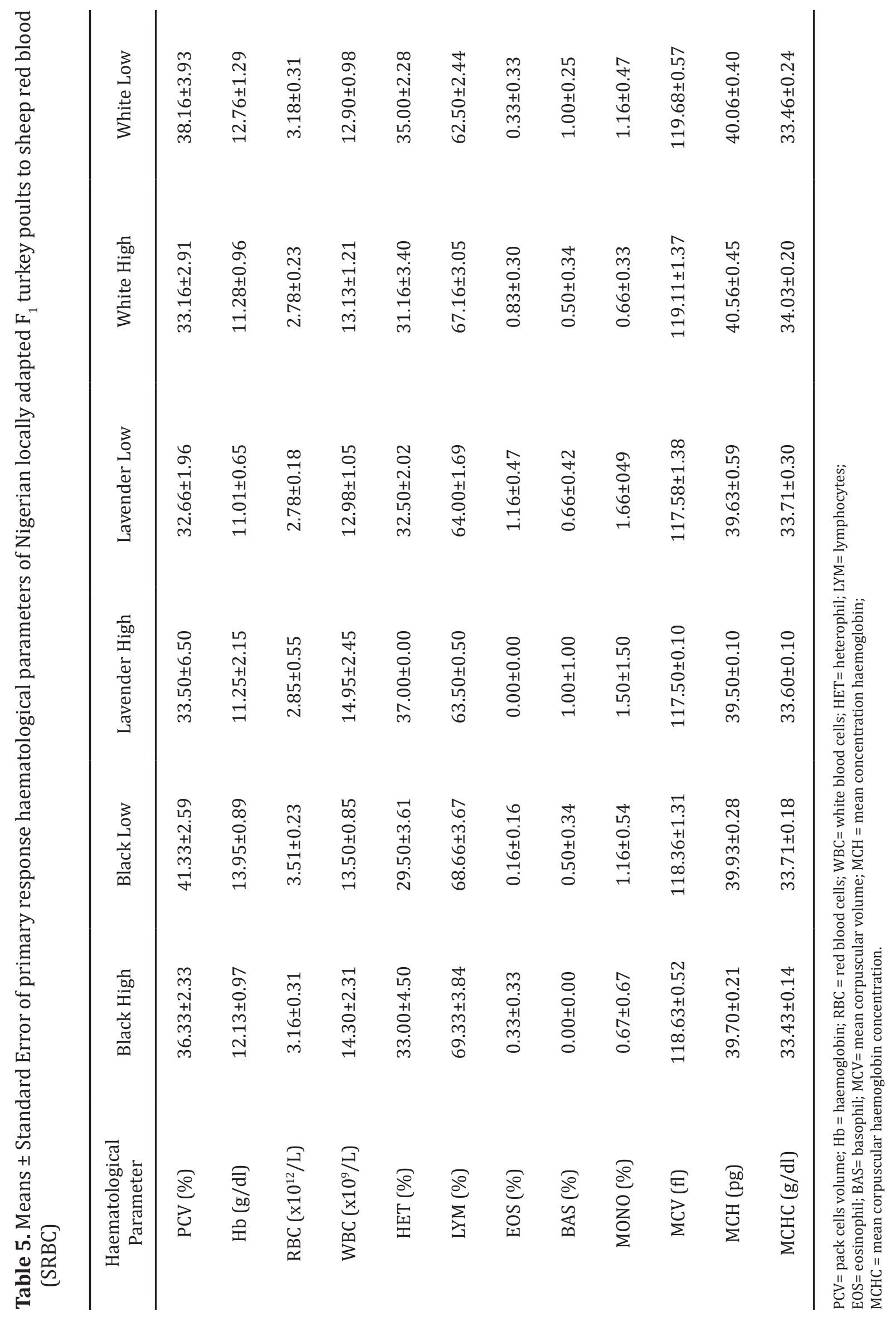


that the inoculation of SRBC does not influence the PCV status of the birds. The mean values of PCV obtained in this study is consistent with the report of haematological parameters, local, crossbreed and exotic turkeys reared in southern Nigeria by Isidahomen et al. (2013) and with the report of haematological parameters of Norfolk and Mammoth turkeys at $8^{\text {th }}$ and $16^{\text {th }}$ weeks of age by Ibrahim (2014), so also with report of haematological parameters of Bronze turkey from Brazil by Schmidt et al. (2009). The haemoglobin $\mathrm{Hb})$ is the protein in the blood that holds the oxygen. The $\mathrm{Hb}$ mean values obtained for the basal as well as the primary response to SRBC are within the normal range of $7.00-13.00 \mathrm{~g} / \mathrm{dl}$ for avian stated by Mitruka and Rawnsley (1997). The results obtained are lower than the values reported of Schmidt et al. (2009) and Isidahomen (2013) but in agree with the report of Ibrahim (2014). Even with the slight increase/decrease after the inoculation observed across all the genotypes of turkey observed in this study, the SRBC has no influence on the $\mathrm{Hb}$ status of the turkey genotypes. The red blood cell count (RBC) is the number of red blood cells which helps to deliver oxygen and carbon dioxide through the body (Isaac et al., 2013). The normal range for $\mathrm{RBC}$ in avian which is $4.21-4.84 \times 10^{12} / \mathrm{L}$ (Mitruka \& Rawnsley, 1997), was higher than the mean values of RBC for the basal and primary responses obtained in this study. This is an indication of anaemia among the turkey genotypes observed in this study. Schmidt et al. (2009) stressed that red cell mass of birds is influenced by environmental factors, age, hormonal and disease. This result is similar to the report of Peters et al. (2011) but contradicts the investigation of Ibrahim (2014) which reported high values of RBC counts above the reference range. The mean corpuscular volume (MCV) shows the average size of the RBC, the mean corpuscular haemoglobin (MCH) tells how much haemoglobin (a protein) is in the typical RBC which carries oxygen to the organs and tissues while the mean corpuscular haemoglobin concentration measures the concentration of haemoglobin in a certain amount of blood (WEBMD, 2019). The MCV and MCH mean values obtained from this study are very high and above the normal range (MCV: 81.60-89.10fl, MCH: 27.20-28.90pg) while the MCHC mean values obtained are slightly above normal range (MCHC: $32.41-33.37 \mathrm{~g} / \mathrm{dl}$ ) for avian stated by Mitruka and Rawnsley (1997). This result is consistent with the reports of Isidahomen et al. (2013) and Peters et al. (2011) for Nigerian native chickens but contradict the findings of Adeyemo (2018) which reported MCV and MCH values below the reference range in Nigerian indigenous chicken genotypes. The White blood cells (WBC) or leukocytes alongside the differentials (heterophils - HET, lymphocytes - LYM, eosinophils - EOS, basophils - BAS and monocytes - MONO) are immune system cells that protect the body against diseases and foreign invaders (Chiaet, 2016). This study revealed that the lymphocytes are the most abundant leukocyte in the peripheral blood of the turkey genotypes which confirm to the similar reports of Bounous et al. (2000) from haematological studies of wild turkeys and Bounous and Stedman (2000) for chickens and turkeys. The basal WBC count and lymphocytes percentage obtained in this study are above the reference ranges (WBC count: 4.07$4.32 \times 10^{9}$ /L, Lymphocytes: $20.00-50.00 \%$ ) stated for avian by Mitruka and Rawnsley (1997). Which indicates that the turkey genotypes observed are healthy with the capability of generating antibodies in the process of phagocytosis and subsequently have high degree of immune response and resistance to diseases (Soetan et al., 2013; Etim et al., 2014), but the heterophil and monocytes percentages are below the stated ranges (Heterophil: 40.00-75.00\%, Monocytes: 5.00-10.00) by Mitruka and Rawnsley (1997), which signifies that they are susceptible to bacteria and fungus infections (Chiaet, 2016) which can be attributed to the management of the birds (Etim et al., 2014). The results obtained in this study is in accordance with the findings of Ibrahim (2014), Isidahomen et al. (2013) and Schmidt et al. (2009) who all reported WBC counts in turkeys which is above the reference value as well as Peters et al. (2011) who also reported WBC counts above the reference value in Nigerian native chickens. Interestingly, the inoculation of the birds with SRBC caused an increase in the WBC counts across the turkey genotypes, which signifies the identification of foreign invaders i.e. SRBC by the immune system of the birds (Chiaet, 2016) with the Lavender High (LH) genotype having the highest WBC primary response mean value and the White Low (WL) genotype having the least. For the other differential counts, the changes in 
the primary response and secondary response mean values varies across the turkey genotypes: the LH has the highest HET mean value for the primary response while the BL has the least; the $\mathrm{BH}$ has the highest LYM mean value for the primary while the WL has the least; the LL has the highest EOS mean value for the primary response while the LH has the least; the WL has the highest BAS mean value; the LL has the highest MONO mean value while the $\mathrm{WH}$ and $\mathrm{BH}$ has the least for the primary response. The variations in the basal and primary response haematological parameters among the turkey genotypes might be due to season, species, immune system, management and nutrition especially protein deficiency (Fudge, 2000; Oladele et al., 2001; Campbell, 2004; Etim et al., 2014; Adeyemo, 2018).

\section{Conclusions}

The $\mathrm{F}_{1}$ turkey poult population studied diverge along the high and low antibody titre in response to the SRBC antigen. The genotype's titre had significant effect on the PCV, Hb, RBC, WBC and BAS of the basal haematological parameters but no significant difference was observed among the primary response haematological parameters. The basal haematological parameters of the Nigerian locally adapted $F_{1}$ turkey poults observed in this study were within the reference ranges of the avian haematological values except the RBC. While the primary response of haematological parameters to SRBC antigen varies along the genotypes with the WBC increasing drastically in all the genotypes signifying the presence of a foreign invader. Thus, the $\mathrm{F}_{1}$ generation of the high antibody titre genotypes (Black high, White high and Lavender high) can be used as foundation stock for selection of local turkeys for high antibody titre.

\section{References}

1. Adeyemo GO, Bolarinwa MO and Ehiabhi O (2018). Body image, social anxiety and psychological distress among young adults. International Journal of Molecular Biology Open Access, 3(4): 197-201. doi: 10.15406/ ijmboa.2018.03.00077

2. Bounous DI and Stedman NL (2000). Normal Avian Hematology: chicken and turkey. In: Feldman BF, Zinkl JG and NC Jain. Schalm's Veterinary Hematology, $5^{\text {th }}$ Ed. Lippincott, Williams and Wilkisn, Philadelphia, pp. 1147-1154.

3. Bounous DI, Wyatt RD, Gibbs PS, Kilburn JV and Quist CF (2000). Normal hematologic and serum biochemical reference intervals for juvenile wild turkeys. Journal of Wildlife Diseases, 36: 393-396.

4. Campbell TW (2004). Hematology of Birds. In: Thrall, M.A. Veterinary Hematology and Clinical Chemistry. Lippincott Williams and Wilkins, Philadelphia, pp. 225-258.

5. Chiaet J (2016). White Blood Cell Types and Functions. Retrieved from https://www.labroots.com/trending/ videos/9734/white-blood-cell-types-functions, February 12, 2019.

6. Etim NN, Williams ME, Akpabio U and Offiong EEA (2014). Haematological parameters and factors affecting their values. Agricultural Sciences, 2(1): 37-47.

7. Fudge AM (2000). Laboratory Medicine-Avian and Exotic Pets. W.B. Saunders Company, Philadelphia, pp. 486.

8. Gross WG, Siegel PB, Hall RW, Domermuth CH and Duboise RT (1980). Production and persistence of antibodies in chickens to sheep erythrocytes. Poultry Science, 59: 205210.

9. Ibrahim MC (2014). Effect of breed, age and sex on growth, haematological, serum biochemical and carcass characteristics of turkeys (Meleagris gallopavo). M.Sc. thesis submitted to the school of postgraduate studies, Ahmadu Bello University, Zaria, Nigeria.

10. Isaac LJ, Abah G, Akpan B and Ekaette IU (2013). Haematological properties of different breeds and sexes of rabbits. Proceedings of the $18^{\text {th }}$ Annual Conference of Animal Science Association of Nigeria. pp. 24-27.

11. Isidahomen CE, Njidda AA and Amaza IB (2013). Effect of genotype on haematology and serum biochemistry values of Turkeys (Meleagris gallopavo) reared in Southern Nigeria. International Journal of Agricultural Biosciences, 2(5): 297-301.

12. Kuehn LA, Price SE, Honaker CF and Siegel PB (2006). Antibody response of chickens to sheep red blood cells: crosses among divergently selected genotypes and relaxed subgenotypes. Poultry Science, 85: 1338-1341.

13. Lamont SJ, Marie-Helene PL, Avigdor C, Jan JP and Henk KP (2003). Selection for disease resistance: direct selection on the immune response. Poultry Genetics, Breeding and Biotechnology. CABI Publishing CAB International Wallingford Oxon OX10 8DE UK. pp. 399-418.

14. Martin AE, Dunnington EA, Gross WB, Briles WE and Siegel PB (1990). Production traits and alloantigen systems in genotypes of chickens selected for high or low antibody responses to sheep erythrocytes. Poultry Science, 68: 871-878.

15. Mitruka BM and Rawnsley HM (1997). Clinical, Biochemical and Hematological reference values in normal experimental animals. $1^{\text {st }}$ edition. New York: Masson Publishing.

16. Ogah DM (2011). Assessing size and conformation of the body of Nigerian indigenous turkeys. Slovak Journal of Animal Science, 44 (1): 21 - 27.

17. Okaroafor ON (2014). Evaluation of factors limiting turkey production in Enugu state and comparison of pathology associated with Newcastle disease in turkeys and cockerels. PhD Submitted to Department of Veterinary 
Medicine Faculty of Veterinary Medicine, University of Nigeria Nsukka. pp. 87.

18. Oladele SB, Ogundipe S, Ayo JO and Esievo KAN (2001). Effect of season and sex on packed cell volume, haemoglobin and total protein of indigenous pigeons in Zaria, Northern Nigeria. Veterinarski Archive, 71(5): $277-$ 286.

19. Peters SO, Gunn HH, Imumorin IG, Agaviezor BO and Ikeobi CON (2011). Haematological studies on frizzled and naked neck genotypes of Nigerian native chickens. Tropical Animal Health Production, 43: 631-638. doi: 10.1007/s11250-010-9743-7

20. Pinard MH, van Arendonk JAM, Nieuwland MGB and van Der Zijpp AJ (1992). Divergent selection for immune responsiveness in chickens: estimation of realized heritability with an animal model. Journal of Animal Science, 70: 2986-2993.

21. Quintavalla F, Bigliardi E and Bertoni P (2001). Blood biochemical base genotype values in the ostrich (Struthio camelus). Food and Agricultural Organization, 21: 61-71.

22. Schmidt EMS, Paulillo AC, Martins GRV, Lapera IV, Testi AJP, Leonildo NJ, Denadai J and Fagliari JJ (2009): Hematology of the bronze turkey (Meleagris gallopavo): variations with age and gender. International Journal of Poultry Science, 8(8): 752-754.

23. Siegel PB and Gross WB (1980). Production and persistence of antibodies to sheep erythrocytes. Poultry Science, 59: 1-5.

24. Soetan KO, Akinrinde AS and Ajibade TO (2013). Preliminary studies on the haematological parameters of cockerels fed raw and processed guinea corn (Sorghum bicolor). Proceedings of $38^{\text {th }}$ Annual Conference of Nigerian Society for Animal Production. pp. 49-52.

25. Tuoyu G, Xiaojing G and Edward JS (2015). Screening for genes involved in antibody response to sheep red blood cells in the chicken, Gallus gallus. Poultry Science, 94(9): $1-9$.

26. van Der Zijpp AJ and Leenstra FR (1980). Genetic analysis of the humoral immune response of White Leghorn chickens. Poultry Science, 59: 1363-1369.

27. WEBMD (2019). What is a Complete Blood Count? Retrieved from https://www.webmd.com/a-to-z-guides/ complete-blood-count, March 23, 2019.

28. Wegmann TG and Smithies O (1966). A simple hemagglutination system requiring small amounts of red cells and antibodies. Transfusion, 6: 67-73. 